\title{
Antioxidizing Enzyme Activities in Chilling-sensitive and Chilling-tolerant Pepper Fruit as Affected by Stage of Ripeness and Storage Temperature
}

\author{
Chae Shin Lim \\ Agriculture Technology Education Center, Gyeongsangnamdo Agricultural Research and Extension \\ Services, Jinju 1085-1, Republic of Korea \\ Seong Mo Kang and Jeoung Lai Cho ${ }^{1}$ \\ Department of Horticulture, Division of Applied Life Science, Gyeongsang National University, \\ Gazwadong 900, Jinju, Gyeongsangnam-do 660-701, Republic of (South) Korea \\ Kenneth C. Gross \\ Produce Quality and Safety Laboratory, USDA/ARS, Beltsville Agricultural Research Center, \\ Building 002, 10300 Baltimore Avenue, Beltsville, MD 20705-2350

\begin{abstract}
Additional INDEX wORDs. Capsicum annuum, carotenoids, ethylene, respiration, surface pitting
Abstract. To study ripening-related chilling injury in pepper (Capsicum annuum L.), chilling-tolerant 'Buchon' and chilling-sensitive 'Nockgwang' fruit were harvested at mature green (MG), breaker (BR), and red-ripe (RR) stages and stored at 1,5 , and $10{ }^{\circ} \mathrm{C}$ for $21 \mathrm{~d}$. 'Buchon' did not show surface pitting (SP) regardless of ripeness stage and storage temperature, whereas 'Nockgwang' at MG and BR exhibited SP at 1 and $5{ }^{\circ} \mathrm{C}$. After 14 days of storage at $1{ }^{\circ} \mathrm{C}$, chilling-sensitive 'Nockgwang' did not show SP when fruit were at the RR stage. Compared with 'Buchon', 'Nockgwang' at MG and BR had more electrolyte leakage increase during storage at 1 and $5{ }^{\circ} \mathrm{C}$. 'Buchon' at all ripeness stages showed significantly higher ethylene production during storage regardless of storage temperatures. Contents of $\beta$-carotene and lycopene increased in both cultivars as ripening progressed. The contents of $\beta$-carotene and lycopene were similar between the two cultivars regardless of storage temperatures and ripeness stages. Susceptibility of pepper fruit to chilling appeared to be related to superoxide dismutase (SOD) and catalase (CAT). Activities of SOD and CAT were much higher in 'Buchon' than 'Nockgwang', more apparently at MG and BR. The results suggest that chilling-tolerant 'Buchon' and fruit at $R R$ could have been equipped with a more efficient antioxidizing system, even if it was not clear whether oxidative stress is a cause or an effect of the CI in pepper.
\end{abstract}

Temperature regulation is the most effective tool for extending the storage life of fresh commodities, including pepper. Pepper fruit are susceptible to chilling injury (CI) below $7{ }^{\circ} \mathrm{C}$ (Paull, 1990) depending on cultivar and stage of ripeness (Meir et al., 1995). During cold storage of pepper, longer storage time and lower temperature caused more severe CI (Risse et al., 1987). Differences in chilling sensitivity at different stages of maturity have been reported in tomato [Solanum lycopersicum L. (Autio and Bramlage, 1986)], mandarin [Citrus reticulata Blanco (Lafuente et al., 1997)], and pepper (Lim et al., 2007; Lin et al., 1993). Ethylene production, respiration, and electrolyte leakage (EL) usually precede or occur concomitantly with visible CI symptoms (Purvis, 2002).

Postharvest surface pitting of fruit at low temperature appears as the localized collapse of the fruit peel (Fung et al., 2004; Lim et al., 2007). The surface pitting (SP) in pepper is characterized by dot pitting followed by sheet pitting (Hardenburg et al., 1986). Oxidative stress is associated with

Received for publication 25 Apr. 2008. Accepted for publication 8 Dec. 2008. We gratefully acknowledge the financial support provided by the Inst. of Agri. \& Life Sci. GNU, Rural Development Administration, and Agricultural R\&D Promotion Center in Korea.

We thank Prof. J.J. Lee and Mr. J.H. Lee for help in enzyme assays.

${ }^{1}$ Corresponding author. E-mail: limsabin@gsnd.net. the appearance of chilling damage in apple [Malus $\times$ domestica Borkh. (Rupasinghe et al., 2000)], cucumber [Cucumis sativus L. (Hariyadi and Parkin, 1991)], pear [Pyrus bretscheideri R. (Ju et al., 1994)], tomato (Malacrida et al., 2006) and the antioxidizing system may play a role in protecting the fruit from chilling (Sala and Lafuente, 1999). Chloroplasts and mitochondria are considered two major sites that produce active oxygen species (AOS) (Purvis et al., 1995). Chilling increases the level of AOS in chilling-sensitive plants. AOS can damage membranes, proteins, and nucleic acid, disrupting cellular homeostasis (Scandalios, 1993). Superoxide dismutase, catalase, ascorbate peroxidase (APX), and glutathione reductase (GR) can efficiently detoxify AOS (Asada, 1994). On the other hand, some antioxidant molecules such as ascorbic acid, glutathione, $\alpha$-tocopherol, carotenoids, and flavonoids can quench AOS (Halliwell and Gutteridge, 1989). Reduction of the chilling in resistant plants may be related to their ability to reduce and/or scavenge free radicals through increased enzyme activity as has been reported in pear fruit (Ju et al., 1994) and maize [Zea mays L. (Zhang et al., 1995)] and rice [Oryza sativa L. (Saruyama and Tanida, 1995)] plants. Sala (1998) observed that APX, catalase (CAT), and GR activities were higher in pitting-tolerant cultivars of mandarin. However, little information is available on the relationship between ripening stage and chilling sensitivity 
of pepper fruit. Nor have the chilling symptoms and related enzymes been compared between chilling-sensitive and -tolerant hot pepper at different ripeness stages.

This experiment was conducted to determine the role of carotenoids and antioxidation-related enzymes in CI development of pepper fruit using two cultivars, chilling-sensitive Nockgwang and chilling-tolerant Buchon, as affected by ripeness stage and storage temperature.

\section{Materials and Methods}

Plant materials and storage conditions. 'Buchon' and 'Nockgwang' hot pepper fruit were harvested in July 2007 from a commercial plastic filmhouse in Daegock, Gyeongnam Province, South Korea. Fruit were harvested at three ripening stages: mature green (full size, dark green), breaker (incipient red color formation), and red-ripe (completely red). Fruit were selected based on the uniformity of size (average weight per fruit: 'Buchon' $\approx 23$ g; 'Nockgwang' $\approx 16$ g). Fruit were washed with tap water and then air-dried at room temperature. To provide similar relative humidity conditions $(90 \%)$ around fruit, five fruit were packed into sealed, perforated low-density polyethylene bags $\left(52 \mu \mathrm{m}\right.$ thick, $24.5 \times 35.5 \mathrm{~cm}$ in size, $\mathrm{O}_{2}$ permeability 345.5 $\mathrm{mL} \cdot \mathrm{m}^{-2} \cdot \mathrm{h}^{-1}$ per $\left.\mathrm{MPa}\right)$. A perforated bag had 12 needle holes (each $0.5 \mathrm{~mm}$ in diameter). Fruit were stored at 1,5 , and $10{ }^{\circ} \mathrm{C}$ for $21 \mathrm{~d}$ and $\mathrm{CO}_{2}$ in the bag was below $1.5 \%$ during storage. To determine the effect of ripening stage on respiration and ethylene production, the bags were opened at 7-d intervals for each measurement, after which all fruit were immediately returned to their original storage conditions until the next measurement.

Lycopene and $\beta$-carotene contents and antioxidizing enzyme activities were measured at the end of the storage. After storage, fruit was cut into small pieces, frozen in liquid $\mathrm{N}_{2}$, and stored at $-70{ }^{\circ} \mathrm{C}$ for enzyme assays.

Surface PITTING. Visible CI symptoms were assessed by rating the degree of SP after storage at $1,5,10{ }^{\circ} \mathrm{C}$ for $21 \mathrm{~d}$ followed by a 2 -d exposure to room temperature $\left(20{ }^{\circ} \mathrm{C}\right)$. Ten panelists were used to perform the evaluation of SP based on the percentage of surface area pitted. The surface pitting index (SPI) was scored on a scale of 0 to 9 , in which $0=$ no pitting, $1=$ $1 \%$ to $10 \%, 2=11 \%$ to $20 \%, 3=21 \%$ to $30 \%, 4=31 \%$ to $40 \%$, $5=41 \%$ to $50 \%, 6=51 \%$ to $60 \%, 7=61 \%$ to $70 \%, 8=71 \%$ to $80 \%$, and $9=$ greater than $80 \%$ of the surface area pitted. Thirty fruit were used for each replication.

SCANNING ELECTRON MiCrosCopy OF PITTING. For scanning electron microscopy (SEM) analysis, five specimens $(3 \times 3 \times 5$ $\mathrm{mm}$ ) for each replication were excised from the most severely pitted as well as nonpitted skin regions of fruit. Specimens were fixed immediately with $3 \%$ glutaraldehyde in $0.2 \mathrm{M} \mathrm{Na}$ phosphate $(\mathrm{pH} 7.0)$ for $4 \mathrm{~h}$ at room temperature. The specimens were postfixed for $2 \mathrm{~h}$ in buffered $2 \%$ osmium tetroxide followed by dehydration in an ethanol series. The specimens were dried to a critical point and mounted on copper holders using double-adhesive carbon tape before coating with gold for $3 \mathrm{~min}$. The coated samples were examined under a JSM6380LV (JEOL, Tokyo, Japan) SEM at $15 \mathrm{kV}$.

Electrolyte LEAKAGE. EL was determined using a slightly modified method of Saltveit (2002). Fruit discs (5 mm diameter) were excised with a stainless steel cork borer. Fifteen fruit were used for each replication. Three discs from each fruit were incubated in a $50-\mathrm{mL}$ plastic conical tube containing $20 \mathrm{~mL}$ of $0.2 \mathrm{M}$ mannitol. Conductivity of the solution was measured at the beginning of the incubation ( $\left.\mathrm{EL}_{0}\right)$ using a conductivity meter (F-54 BW; Horiba, Kyoto, Japan). The disc samples were agitated on a flat-bed shaker at $60 \mathrm{rpm}$ for $24 \mathrm{~h}$ at $25^{\circ} \mathrm{C}$ and the conductivity of the solution was again measured $\left(\mathrm{EL}_{24}\right)$. To measure residual electrolytes remaining in the discs, they were frozen at $-20{ }^{\circ} \mathrm{C}$ for $24 \mathrm{~h}$ and then thawed before total conductivity of the solution was measured $\left(E L_{t}\right)$. EL was calculated using the following equation (Lim et al., 2007):

$$
\mathrm{EL}(\%)=\left[\left(\mathrm{EL}_{24}-\mathrm{EL}_{0}\right) /\left(\mathrm{EL}_{\mathrm{t}}-\mathrm{EL}_{0}\right)\right] \times 100 \text {. }
$$

RESPIRATION AND ETHYLENE PRODUCTION. Respiration and ethylene production were estimated using a static state method. Three hot peppers weighed at the beginning of the experiment were put in a 1-L plastic jar (Nalgene, Rochester, NY) after equilibrating for $1 \mathrm{~h}$ at $20^{\circ} \mathrm{C}$. The jars were kept for another $1 \mathrm{~h}$ at $20^{\circ} \mathrm{C}$, and $1 \mathrm{~mL}$ of headspace gas was then withdrawn using a gas-tight glass syringe. Carbon dioxide and ethylene concentration were analyzed using the gas chromatograph equipped with a packed column (HP19001A-NO1; Agilent Technologies, Santa Clara, CA). Both oven and inlet temperatures were $100{ }^{\circ} \mathrm{C}$ and the back inlet, front detector, and back detector were 375,250 , and $150{ }^{\circ} \mathrm{C}$, respectively. Twenty-seven fruit for hot pepper were used for each replication.

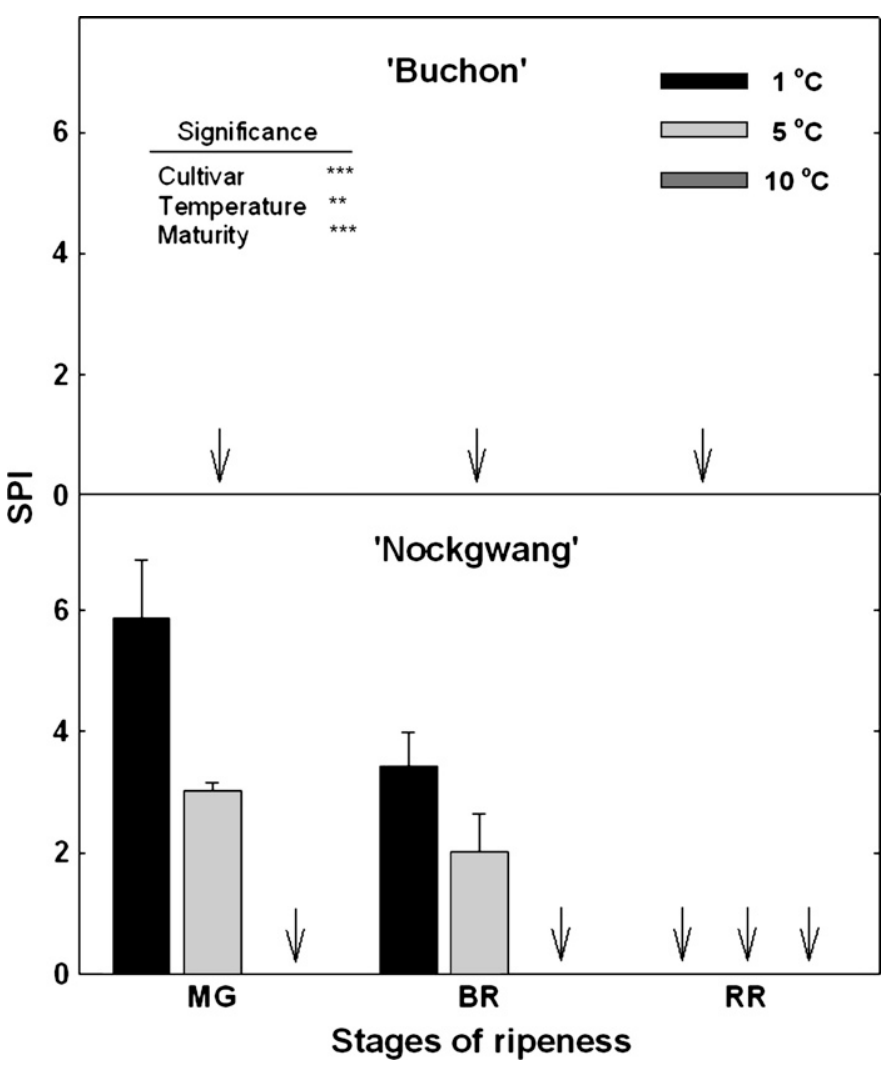

Fig. 1. Effect of ripeness on surface pitting index (SPI) of pepper fruit. Chillingtolerant ('Buchon') and chilling-sensitive ('Nockgwang') peppers were stored at 1,5 , or $10^{\circ} \mathrm{C}$ for $21 \mathrm{~d}$ and then exposed to room temperature for $2 \mathrm{~d}$ before evaluation; $\mathrm{MG}=$ mature green (full size, dark green); $\mathrm{BR}=$ breaker (incipient red color formation); $\mathrm{RR}=$ ripe (completely red). Arrows indicate no pitting occurred after storage. The SPI was on a scale of 0 to 9 , in which $0=$ no pitting, $1=1 \%$ to $10 \%, 2=11 \%$ to $20 \%, 3=21 \%$ to $30 \%, 4=31 \%$ to $40 \%, 5=41 \%$ to $50 \%, 6=51 \%$ to $60 \%, 7=61 \%$ to $70 \%, 8=71 \%$ to $80 \%$, and $9=$ greater than $80 \%$ of the surface area pitted. Vertical bars indicate $\operatorname{SE}(\mathrm{n}=3)$. **, ***Significant at $P=0.01$ or 0.001 , respectively. 
Determination of Carotenoids. One gram of frozen samples was homogenized using a mortar and pestle in the presence of liquid $\mathrm{N}_{2}$. Sixteen milliliters of acetone-hexane solvent $(4: 6 \mathrm{v} / \mathrm{v})$ was added to the pepper homogenate and mixed in a test tube. An aliquot was taken from the upper phase of the solution for measurement of optical density at 663 , 645,505 , and $453 \mathrm{~nm}$ in a spectrophotometer. Lycopene and $\beta$-carotene contents were calculated according to the equations developed by Nagata and Yamashita (1992):

$\beta$-carotene $(\mathrm{mg} / 100 \mathrm{~mL}$ of extract $)=0.216 \times A_{663}-1.22$

$$
\times A_{645}-0.304 \times A_{505}+0.452 \times A_{453} \text {; }
$$

Lycopene $(\mathrm{mg} / 100 \mathrm{~mL}$ of extract $)=-0.0458 \times \mathrm{A}_{663}+0.204$

$$
\times A_{645}+0.372 \times A_{505}-0.0806 \times A_{453} \text {. }
$$

APX activity was measured by the methods of Nagano and Asada (1981). The reaction mixture contained $500 \mu \mathrm{L}$ of 100 mM K-P buffer (pH 7.0), $100 \mu \mathrm{L}$ of $5 \mathrm{~mm}$ ascorbate, $250 \mu \mathrm{L}$ of distilled water, and $50 \mu \mathrm{L}$ of enzyme extract. APX activity was measured by ascorbate oxidation at $290 \mathrm{~nm}$ in the presence of $100 \mu \mathrm{L}$ of $1 \mathrm{~mm} \mathrm{H}_{2} \mathrm{O}_{2}$. The final reaction volume was adjusted to $1 \mathrm{~mL}$. The unit for APX activity was micromoles of ascorbate oxidized per minute per milligram of protein.

CAT activity was measured by Blume and McClure (1980). The reaction mixture contained $500 \mu \mathrm{L}$ of $100 \mathrm{~mm}$ K-P buffer (pH 7.8), $200 \mu \mathrm{L}$ of distilled water, and $200 \mu \mathrm{L}$ of enzyme extract. The reaction was started by adding $100 \mu \mathrm{L}$ of $50 \mathrm{~mm}$ $\mathrm{H}_{2} \mathrm{O}_{2}$ in a final volume of $1 \mathrm{~mL}$ and absorbance was measured at $240 \mathrm{~nm}$. The unit for CAT activity was micromoles of hydrogen peroxide oxidized per minute per milligram of protein.
Lycopene and $\beta$-carotene are expressed as $\mathrm{mg} \cdot \mathrm{kg}^{-1}$ fresh weight. Ten fruit were used for each replication.

ANTIOXIDIZING ENZYME ACTIVITIES. Fruit $(0.5 \mathrm{~g}$ fresh weight from 10 fruit) stored at $-70{ }^{\circ} \mathrm{C}$ were pulverized in a cold mortar and pestle with $10 \%$ polyvinylpolypyrrolidone and then homogenized with $5 \mathrm{~mL}$ of cold $50 \mathrm{~mm}$ potassium phosphate buffer (K-P buffer), $\mathrm{pH} 7.0$, containing 5 $\mathrm{mL}$ ethylenediamine tetraacetic acid (EDTA) and $0.1 \mathrm{~mm}$ ascorbate at 4 ${ }^{\circ} \mathrm{C}$. The homogenate was centrifuged at $13,000 g_{\mathrm{n}}$ for $20 \mathrm{~min}$ at $4{ }^{\circ} \mathrm{C}$. The supernatant was used as an enzyme extract. Activities of all enzymes are expressed as specific activities. Proteins were determined by the method of Bradford (1976) using bovine serum albumin as a standard. Ten fruit were used for each replication.

Superoxide dismutase (SOD) was assayed spectrophotometrically by determining the production of superoxide radicals generated from xanthine-xanthine oxidase reaction using the methods of Kenyon and Duke (1985). Cytochrome C was used as an indicator of superoxide radical production. The reaction mixture consisted of $500 \mu \mathrm{L}$ of 100 mм K-P buffer ( $\mathrm{pH} 7.8$, containing $0.2 \mathrm{~mm}$ EDTA), $100 \mu \mathrm{L}$ of $1 \mathrm{~mm}$ xanthine monosodium salt, $100 \mu \mathrm{L}$ of $100 \mu \mathrm{M}$ cytochrome $\mathrm{C}, 80$ to 120 $\mu \mathrm{L}$ of enzyme extract, and 80 to 120 $\mu \mathrm{L}$ of distilled water. The reaction was started by adding $100 \mu \mathrm{L}$ of xanthine oxidase in a final volume of $1 \mathrm{~mL}$. One unit of SOD activity was defined as the amount of enzyme that causes $50 \%$ inhibition of cytochrome $\mathrm{C}$ reduction at $550 \mathrm{~nm}$.
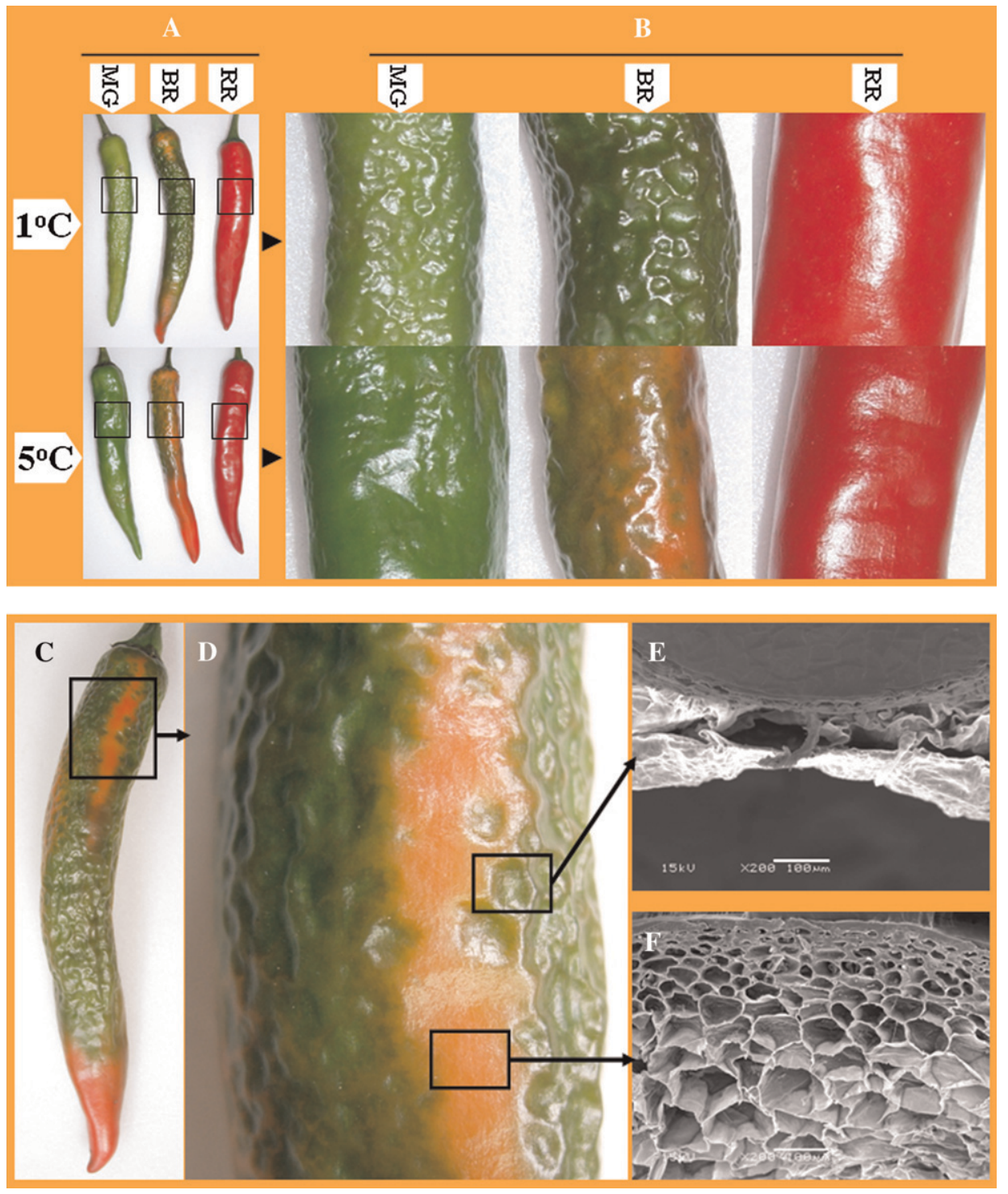

Fig. 2. Development of chilling-induced pitting on chilling-sensitive ('Nockgwang') pepper skin. Pepper fruit were stored at 1 and $5{ }^{\circ} \mathrm{C}$ for $21 \mathrm{~d}$ and then exposed to room temperature for $2 \mathrm{~d}$; MG = mature green (full size, dark green); $\mathrm{BR}=$ breaker (incipient red color formation); $\mathrm{RR}=$ ripe (completely red). Photographs of 'Nockgwang' at $10{ }^{\circ} \mathrm{C}$ were not shown here because no surface pitting occurred in these fruit. The skin from the black square areas in $\mathbf{A}$ and $\mathbf{C}$ were magnified at $6 \times$ in $\mathbf{C}$ and $3.5 \times$ in $\mathbf{D}$, respectively. (E-F) Scanning electron microscopy of a cross-section of the skin from the square areas in $\mathbf{D}$ at $200 \times$ magnification; bar $=100 \mu \mathrm{m}$. 
GR activity was measured by the methods of Foyer and Halliwell (1976). The reaction mixture consisted of $500 \mu \mathrm{L}$ of $200 \mathrm{~mm} \mathrm{~K}-\mathrm{P}$ buffer (pH 7.8), $100 \mu \mathrm{L}$ of $30 \mathrm{~mm} \mathrm{MgCl}_{2}, 50$ $\mu \mathrm{L}$ of distilled water, $100 \mu \mathrm{L}$ of $\beta$-nicotinamide adenine dinucleotide phosphate (NADPH), and $150 \mu \mathrm{L}$ of enzyme extract. GR was assayed by measuring the rate of NADPH oxidation at $340 \mathrm{~nm}$ by adding $100 \mu \mathrm{L}$ of $5 \mathrm{~mm}$ glutathione in a final volume of $1 \mathrm{~mL}$. The unit for GR activity was micromoles of NADPH oxidized per minute per milligram of protein.

Statistical analysis. All the experiments were conducted with three replicates in a completely randomized design. Analysis of variance (ANOVA) was performed using SAS (Version 8.0; SAS Institute, Cary, NC). ANOVA was used to determine the effects of temperature, cultivar, and maturity.

\section{Results and Discussion}

There were significant differences in susceptibility of pepper fruit to chilling not only between cultivars, but also their ripening stages when stored at 1,5 , and $10^{\circ} \mathrm{C}$ for $21 \mathrm{~d}$ (Fig. 1). 'Buchon' fruit were tolerant to CI development, whereas 'Nockgwang' fruit were sensitive to this disorder. No SP occurred in 'Buchon' at any of the ripening stages studied regardless of storage temperature, whereas 'Nockgwang' at both mature green (MG) and breaker (BR) stages exhibited SP at 1 and $5{ }^{\circ} \mathrm{C}$ (Figs. 1 and 2). SP development in 'Nockgwang' was more severe at MG than $\mathrm{BR}$, and lower temperature induced more SP development. After storage at $1{ }^{\circ} \mathrm{C}$, SPI of 'Nockgwang' fruit at MG and BR were 5.9 and 3.4, respectively. 'Nockgwang' stored at $10{ }^{\circ} \mathrm{C}$ showed no SP. After 21 $\mathrm{d}$ of storage at $1{ }^{\circ} \mathrm{C}$, chilling-sensitive 'Nockgwang' did not show SP symptoms when fruit were at redripe (RR). The absence of SP on ripe fruit was also observed in bell pepper (Lim et al., 2007; Lin et al., 1993). Susceptibility of MG and BR 'Nockgwang' fruit to chilling temperatures suggests a role of chloroplasts in the development of CI in pepper fruit. In the present study, the pitted regions of 'Nockgwang' at BR remained green and

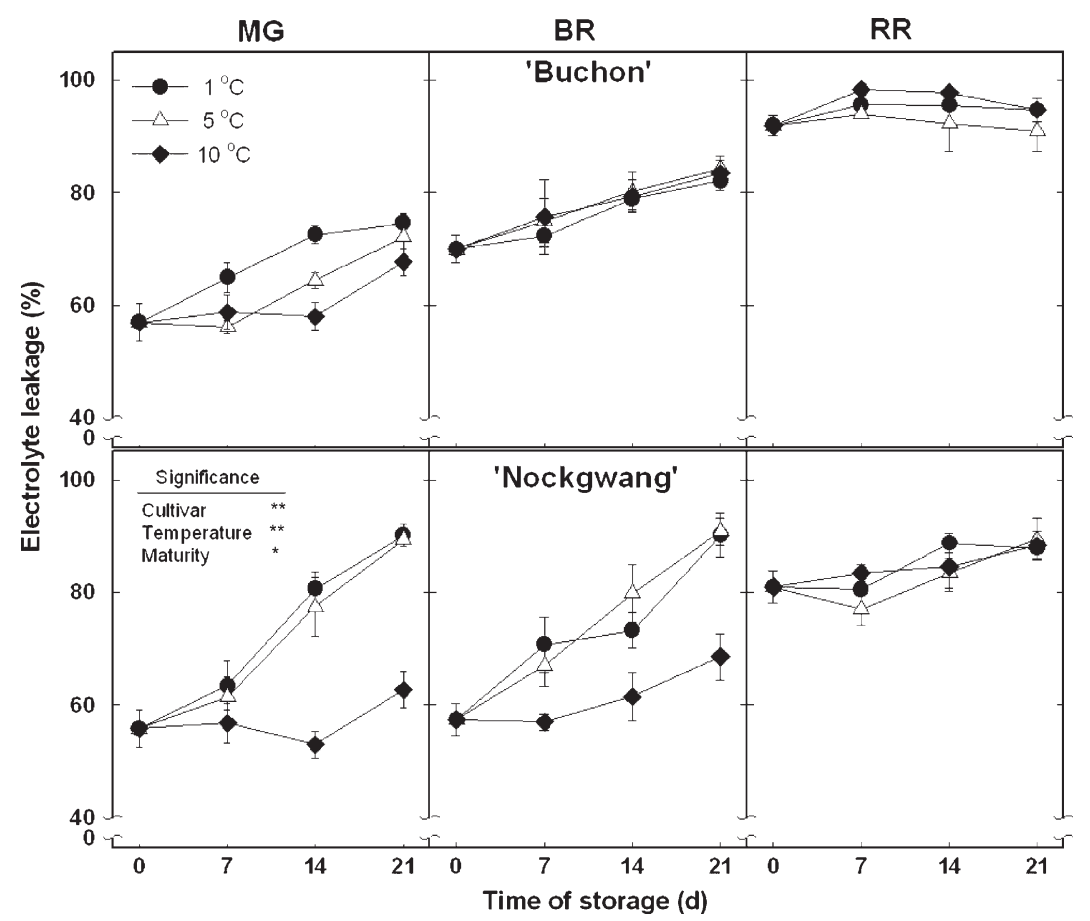

Fig. 3. Changes in electrolyte leakage of pepper at 1,5 , or $10^{\circ} \mathrm{C}$ as affected by ripeness stage. Chilling-tolerant ('Buchon') and chilling-sensitive ('Nockgwang') peppers were harvested at three ripeness stages $[\mathrm{MG}=\mathrm{mature}$ green (full size, dark green); $\mathrm{BR}=$ breaker (incipient red color formation); $\mathrm{RR}=$ ripe (completely red)] and stored for $21 \mathrm{~d}$. Vertical bars indicate SE $(\mathrm{n}=3)$. Data at $21 \mathrm{~d}$ were used for analysis of variance. *, **Significant at $P=0.05$ or 0.01 , respectively.

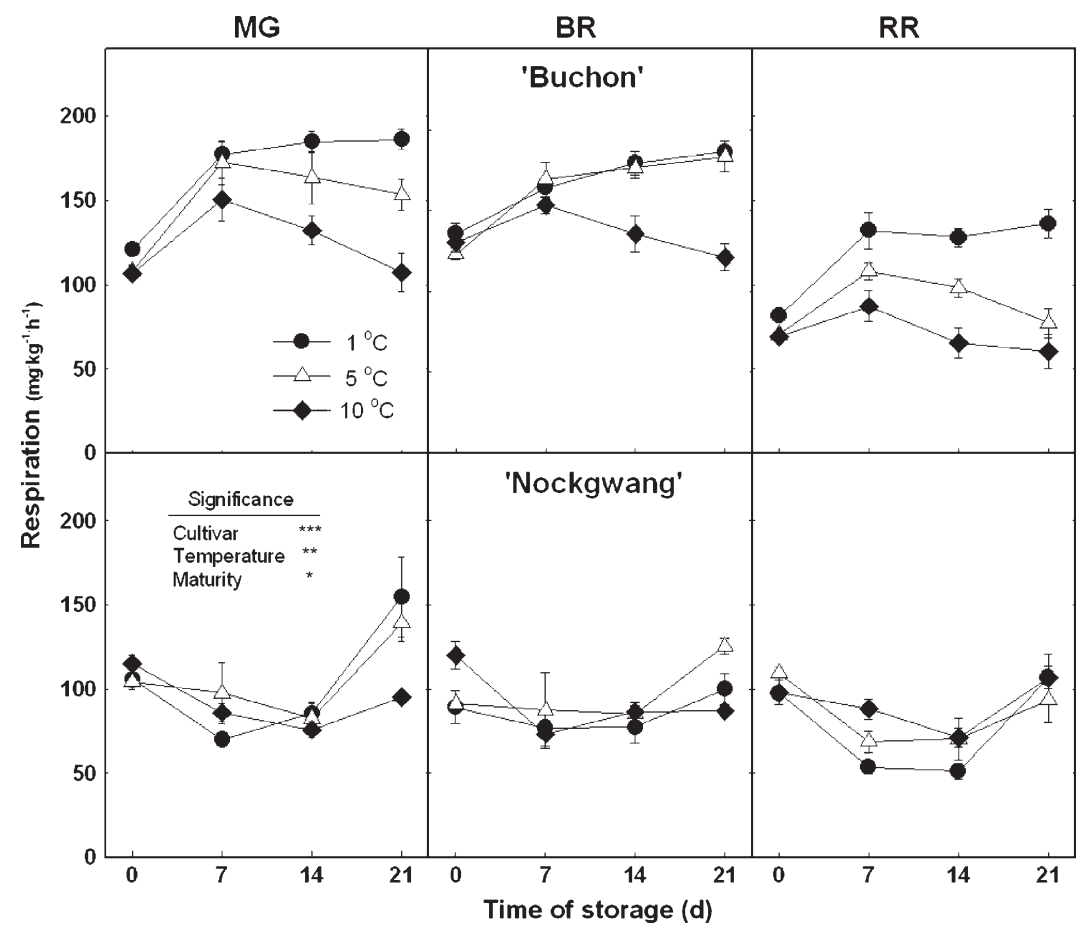

Fig. 4. Changes in respiration of pepper at 1,5 , or $10^{\circ} \mathrm{C}$ as affected by ripeness stage. Chilling-tolerant ('Buchon') and chilling-sensitive ('Nockgwang') peppers were harvested at three ripeness stages $[\mathrm{MG}=$ mature green (full size, dark green); $\mathrm{BR}=$ breaker (incipient red color formation); RR = ripe (completely red)] and stored for $21 \mathrm{~d}$. Vertical bars indicate SE $(\mathrm{n}=3)$. Data at $21 \mathrm{~d}$ were used for analysis of variance. *,**,*** Significant at $P=0.05$, 0.01 , or 0.001 , respectively. 
exhibited a loss of cellular integrity, whereas unpitted regions of the same fruit had normal pigmentation and a depression-free appearance without damaged cells (Fig. 2). CI caused thylakoid unstacking and structural damage to chloroplasts in chillingsensitive tomato fruit (Marangoni and Stanley, 1989).

Ripeness induced an increase of EL in pepper fruit (Fig. 3). Compared with MG fruit, RR fruit had 1.6- and 1.4-fold higher initial EL in 'Buchon' and 'Nockgwang', respectively. The higher EL at the RR stage may be attributed to increased membrane permeability as senescence progressed (Lurie and Ben-Yehoshua, 1986). In MG and BR fruit at 1 and $5{ }^{\circ} \mathrm{C}$, EL increased rapidly in chilling-sensitive 'Nockgwang', whereas it increased to a lesser extent, albeit steadily, in chilling-tolerant 'Buchon'. The higher EL increase in 'Nockgwang' at $\mathrm{MG}$ and $\mathrm{BR}$ reveals that fruit at those stages are susceptible to chilling temperatures during storage. The fact that 'Buchon' fruit exhibited an attenuated increase in EL during chilling suggests that this cultivar may be equipped with a mechanism that protects membranes from deleterious chilling-induced changes. It has been reported that maintaining the membrane in a liquid-crystalline state is more important in chilling-tolerant plants than in chilling-sensitive plants (Marangoni et al., 1996). Increased EL was associated with the appearance of CI symptoms in many sensitive plant tissues (Saltveit, 2002).

During the first few days of storage, respiration decreased in 'Nockgwang' but increased in 'Buchon' (Fig. 4). In general, the lower temperature induced higher respiration in both cultivars regardless of ripeness. Ethylene production of both cultivars increased during the first $7 \mathrm{~d}$ of storage and then decreased by the end of storage regardless of temperature (Fig. 5). It is interesting to note that, regardless of ripeness stage and temperature, 'Buchon' showed significantly higher ethylene production during storage compared with 'Nockgwang'. After $7 \mathrm{~d}$ of storage, ethylene production of 'Buchon' was $\approx 10$ fold higher than that of 'Nockgwang'. There have been several studies that indicated a role for

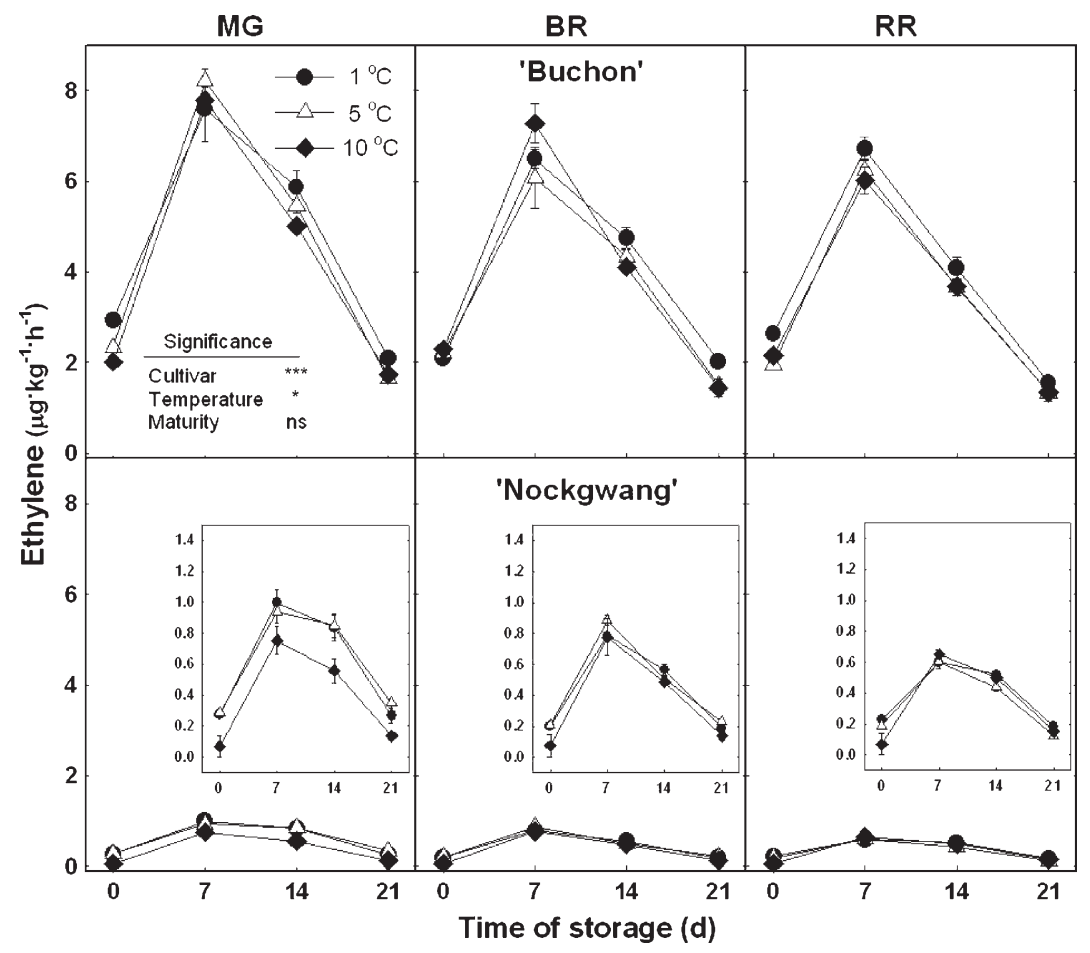

Fig. 5. Changes in ethylene production of pepper at 1,5 , or $10{ }^{\circ} \mathrm{C}$ as affected by ripeness stage. Chilling-tolerant ('Buchon') and chilling-sensitive ('Nockgwang') peppers were harvested at three ripeness stages [MG $=$ mature green (full size, dark green); $\mathrm{BR}=$ breaker (incipient red color formation); RR = ripe (completely red)] and stored for $21 \mathrm{~d}$. Vertical bars indicate SE $(\mathrm{n}=3)$. Data at $21 \mathrm{~d}$ were used for analysis of variance. NS, *, $* * *$ Nonsignificant or significant at $P=0.05$ or 0.001 , respectively.

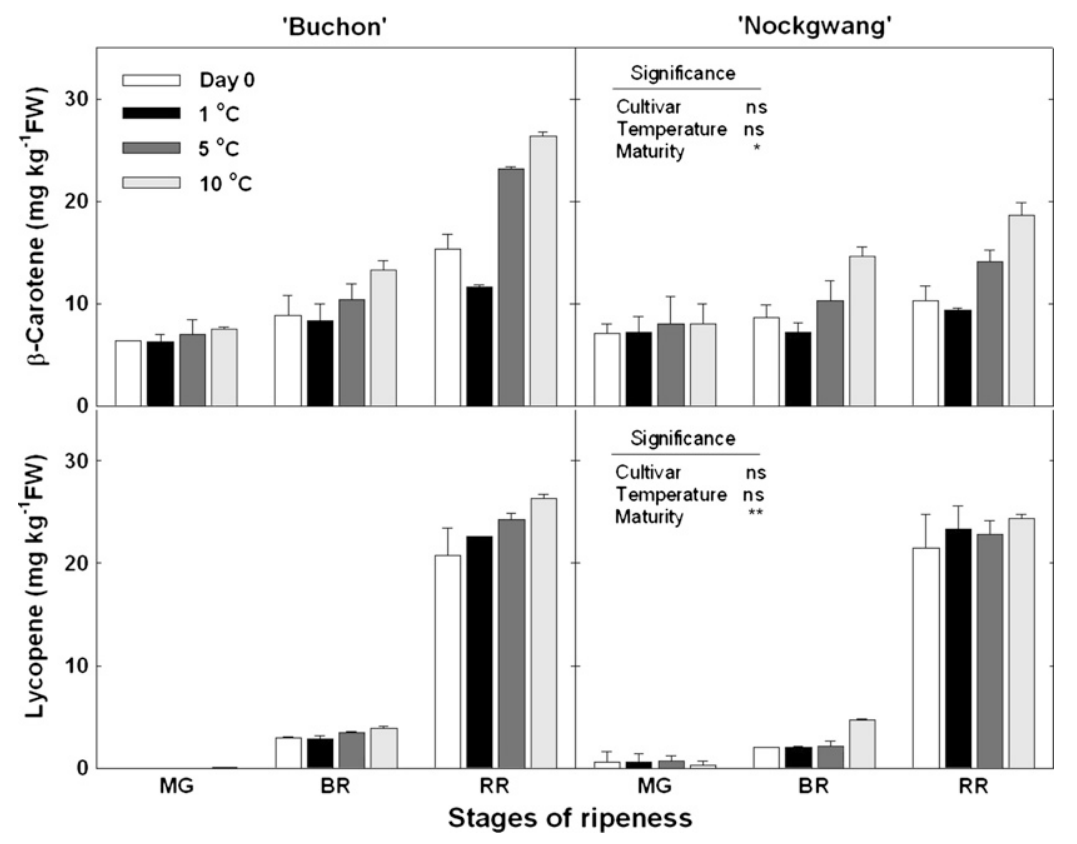

Fig. 6. Effect of ripeness on $\beta$-carotene and lycopene content of pepper fruit stored at 1,5 , or $10{ }^{\circ} \mathrm{C}$ for $21 \mathrm{~d}$. Chilling-tolerant ('Buchon') and chilling-sensitive ('Nockgwang') peppers were harvested at three ripeness stages: $\mathrm{MG}=$ mature green (full size, dark green); $\mathrm{BR}=$ breaker (incipient red color formation); $\mathrm{RR}=$ ripe (completely red). Vertical bars indicate SE $(n=3)$. The white bar indicates carotenoid content at $0 \mathrm{~d}$. NS, * or **Nonsignificant or significant at $P=0.05$, or 0.01 , respectively. 


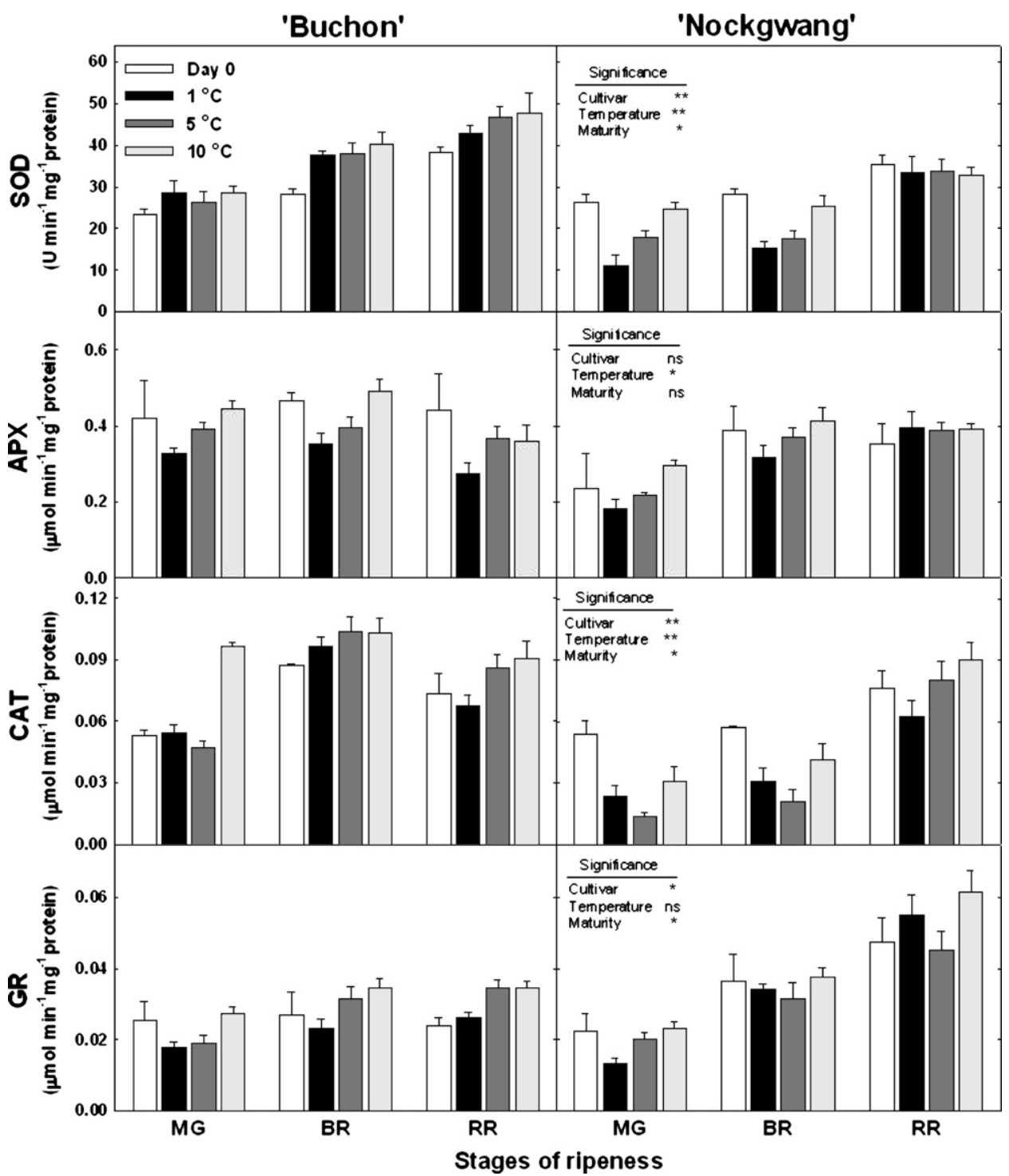

Fig. 7. Effect of ripeness on superoxide dismutase (SOD), ascorbate peroxidase (APX), catalase (CAT), and glutathione reductase (GR) activities of pepper stored at 1,5 , or $10{ }^{\circ} \mathrm{C}$ for $21 \mathrm{~d}$. Chilling-tolerant ('Buchon') and chilling-sensitive ('Nockgwang') peppers were harvested at three ripeness stages: $\mathrm{MG}=$ mature green (full size, dark green); $\mathrm{BR}=$ breaker (incipient red color formation); $\mathrm{RR}=$ ripe (completely red). Vertical bars indicate $\mathrm{SE}$ $(\mathrm{n}=3)$. The white bar indicates enzyme activities at $0 \mathrm{~d}$. Ns, * or **Nonsignificant or significant at $P=0.05$, or 0.01 , respectively.

ethylene in increasing chilling tolerance. Ethylene application significantly reduced CI in muskmelon (Cucumis melo L.) (Lipton and Aharoni, 1979), sweetpotato (Ipomoea batatas L.) (Buescher, 1977), and tomato plants (Ciardi et al., 1997). Tomato fruit with a higher rate of ethylene production exhibited a lower incidence of CI during low-temperature storage (Hong and Gross, 2000).

In the present study, 'Buchon' with higher ethylene production exhibited no CI symptoms at $1{ }^{\circ} \mathrm{C}$. However, it is difficult to conclude that higher ethylene production was a casual factor in enhancing this chilling tolerance.

Chilling stress induces synthesis and accumulation of AOS leading to a loss of membrane integrity (Purvis and Shewfelt, 1993) and appearance of chilling damage in fruit (Hodges et al., 2004). The balance between formation and detoxification of AOS is critical to cell survival during low-temperature storage (Zhang et al., 1995). Antioxidants such as $\beta$-carotene and lycopene as well as antioxidizing enzymes such as SOD, APX, CAT, and GR play an important role in preventing plants from AOS attack (Kang and Saltveit, 2002; Sala and Lafuente, 2004; Scandalios, 1993). The present study shows that the amount of antioxidants and the activities of antioxidizing enzymes vary with cultivar and ripeness in pepper fruit.

The content of $\beta$-carotene and lycopene increased in both 'Buchon' and 'Nockgwang' as ripening progressed (Fig. 6). Both cultivars at BR and RR showed an increase in $\beta$ carotene as storage temperature increased; no such increase was observed in either cultivar at MG. After storage for $21 \mathrm{~d}$ at 1,5 , and 10 ${ }^{\circ} \mathrm{C}$, the lycopene content of both cultivars was substantially higher in fruit at the RR stage than at MG or BR. Carotenoids, antioxidants in plant tissues, react with AOS, mainly with peroxide radicals and singlet molecular oxygen (Namiki, 1990). Lycopene is a powerful antioxidant that acts as the most efficient singlet oxygen quencher among the carotenoids (Di Mascio et al., 1989). Taking our results together with those of previous reports, it can be concluded that a higher level of carotenoids in RR fruit may have contributed to prevention of CI. However, regardless of storage temperature and ripeness stage, lycopene contents were similar between chilling-tolerant 'Buchon' and chilling-sensitive 'Nockgwang'. In addition, 'Nockgwang' at RR at $1{ }^{\circ} \mathrm{C}$ (without SP) showed similar or lower $\beta$-carotene content compared with fruit at $\mathrm{MG}$ or $\mathrm{BR}$ at $5{ }^{\circ} \mathrm{C}$ (with $\mathrm{SP}$ ). Thus, it is reasonable to conclude that carotenoids do not play a critical role in preventing these pepper cultivars from developing SP during cold storage.

After storage for $21 \mathrm{~d}$, 'Buchon' exhibited much higher SOD activity than 'Nockgwang' regardless of ripeness stage or storage temperature (Fig. 7). In general, SOD activity in both cultivars increased as fruit ripening progressed. Storage temperature did not appear to affect SOD activity in 'Buchon' but did in 'Nockgwang' at MG and BR. It is possible that 'Buchon', having higher SOD activity at all temperatures, may have an enhanced ability to dismutate superoxide radicals from mitochondria, a major source of AOS production in green pepper at lower temperature (Purvis et al., 1995). This possible role of SOD in preventing pepper fruit from developing CI cannot be ruled out in 'Nockgwang'. Lower temperature caused lower SOD activity in 'Nockgwang' at MG and BR that showed CI symptoms. 
In general, higher temperature increased APX activity more in both Buchon and Nockgwang cultivars at MG and BR. In fruit at RR, APX activities were similar between storage temperatures in both cultivars except for 'Buchon' at $1{ }^{\circ} \mathrm{C}$, which displayed the lowest level. 'Buchon' at MG only exhibited higher APX activity than 'Nockgwang' at the same ripeness stage regardless of storage temperature. CAT activities were higher in 'Buchon' than in 'Nockgwang' at all storage temperatures when fruit were at MG and BR. CAT activities, however, were similar between cultivars at RR. In general, both cultivars had a higher level of CAT activity at higher temperature. GR activities were higher in pitting-tolerant cultivars of mandarin fruit (Sala, 1998). However, there was no difference in GR activities between chilling-tolerant and -sensitive cultivars when pepper fruit were at MG and BR. In addition, GR of 'Nockgwang' at RR was much higher than 'Buchon' at the same ripeness stage regardless of storage temperature.

Higher $\mathrm{H}_{2} \mathrm{O}_{2}$ content and lower activities of SOD and CAT were observed in chilling-sensitive pear fruit than tolerant fruit after storage at $0{ }^{\circ} \mathrm{C}$ (Ju et al., 1994). In the present study, SOD and CAT activities were higher in chilling-tolerant 'Buchon' than in chilling-sensitive 'Nockgwang'. This trend was more apparent in fruit at MG and BR, the stages at which fruit are more susceptible to SP symptoms (Lim et al., 2007; Lin et al., 1993). This may indicate a lesser ability of 'Nockgwang' to remove cold-induced $\mathrm{H}_{2} \mathrm{O}_{2}$ and superoxide radicals at $\mathrm{MG}$ and BR. The $\mathrm{H}_{2} \mathrm{O}_{2}$ and superoxide radicals resulted in generation of more dangerous $\mathrm{OH}^{*}$ radicals and increased $\mathrm{CI}$ in the fruit peel (Sala, 1998). It was reported that SOD and APX activities were higher in chilling-tolerant than in chilling-sensitive cucumbers (Shen et al., 1999). However, APX activity was higher in chilling-tolerant 'Buchon' than in chilling-sensitive 'Nockgwang' only at MG.

An increase in red pigment of peppers appeared to be associated with elevated activities of antioxidizing enzymes. For example, after storage at $1{ }^{\circ} \mathrm{C}$, chilling-sensitive 'Nockgwang' at RR did not exhibit SP symptoms with higher levels of SOD, CAT, and GR activities at all storage temperatures. Schantz et al. (1995) reported that SOD, APX, and GR increased during the chloroplast-to-chromoplast transition in pepper fruit.

In conclusion, susceptibility of pepper fruit to chilling appears to be related to SOD and CAT. Although it is not clear whether oxidative stress is a cause or an effect of CI in cold-stored peppers or whether the differences in enzyme activities are great enough to account for the physiological differences in chilling sensitivity, the results suggest that both chilling-tolerant and ripe fruit may have a more efficient antioxidizing system.

\section{Literature Cited}

Asada, K. 1994. Production and action of active oxygen species in photosythetic tissues, p. 77-104. In: Foyer, C.H., and P.M. Mullineaus (eds.). Causes of photooxidative stress and amelioration of defense systems in plants. CRC Press, Boca Raton, FL.

Autio, W.R. and W.J. Bramlage. 1986. Chilling sensitivity of tomato fruit in relation to ripening and senescence. J. Amer. Soc. Hort. Sci. 111:201-204.

Blume, D.E. and J. McClure. 1980. Developmental effects of Sandz 6706 on activities of enzymes of phenolic and general metabolism in barely shoots grown in the dark or under low of high intensity light. Plant Physiol. 65:234-238.

Bradford, M.M. 1976. A rapid and sensitive method for the quantitation of microgram quantities of protein utilizing the principle of protein-dye binding. Anal. Biochem. 732:248-254.
Buescher, R.W. 1977. Hard core in sweet potato roots as influenced by cultivar, curing, and ethylene. HortScience 12:326-327.

Ciardi, J.A., J. Diekman, and M.D. Orzolek. 1997. Increased ethylene synthesis enhanced chilling tolerance in tomato. Physiol. Plant. 101:333-340.

Di Mascio, P., S. Kaiser, and H. Sies. 1989. Lycopene as the most efficient biological carotenoid singlet oxygen quencher. Arch. Biochem. Biophys. 274:532-538.

Foyer, C.H. and B. Halliwell. 1976. The presence of glutathione and glutathione reductase in chloroplasts: A proposed role in ascorbic acid metabolism. Planta 133:21-25.

Fung, R.W.M., C.Y. Wang, D.L. Smith, K.C. Gross, and M. Tian. 2004. MeSA and MeJA increase steady-stage transcript levels of alternative oxidase and resistance against chilling injury in sweet peppers (Capsicum annuum L.). Plant Sci. 166:711-719.

Halliwell, B. and J.M.C. Gutteridge. 1989. Free radicals in biology and medicine. Clarendon Press, Oxford, UK.

Hardenburg, R.E., A.E. Watada, and C.Y. Wang. 1986. The commercial storage of fruits, vegetables, and florist and nursery stocks. U.S. Dept. Agr. Agr. Hdbk. 66.

Hariyadi, P. and K.L. Parkin. 1991. Chilling-induced oxidative stress in cucumber fruits. Postharvest Biol. Technol. 1:33-45.

Hodges, D.M., G.E. Lester, K.D. Munro, and P.M.A. Toivonen. 2004. Oxidative stress: Importance for postharvest quality. HortScience 39:924-929.

Hong, J.H. and K.C. Gross. 2000. Involvement of ethylene in development of chilling injury in fresh-cut tomato slices during cold storage. J. Amer. Soc. Hort. Sci. 125:736-741.

Ju, Z., Y. Yuan, C. Liou, S. Zhan, and S. Xiu. 1994. Effects of low temperature on $\mathrm{H}_{2} \mathrm{O}_{2}$ and heart browning of Chili and Yali pear (Pyrus bretscheideri R.). Scientia Agricultra Sinica 27:77-81.

Kang, H.M. and M.E. Saltveit. 2002. Antioxidant enzymes and DPPH-radical scavenging activity in chilled and heat-shocked rice (Oryza sativa L.) seedlings radicles. J. Agr. Food Chem. 50: 513-518.

Kenyon, J.H. and S.O. Duke. 1985. Effect of acifluorfen on endogenous antioxidants and protective enzymes in cucumber (Ducumis sativas L.) cotyledons. Plant Physiol. 79:862-866.

Lafuente, M.T., M.A. Martínez-Téllez, and L. Zacarías. 1997. Abscisic acid in the response of 'Fortune' mandarin to chilling. Effect of maturity and high temperature conditioning. J. Sci. Food Agr. 73:494-502.

Lim, C.S., S.M. Kang, K.C. Gross, A.B. Woolf, and J.L. Cho. 2007. Bell pepper (Capsicum annuum L.) fruits are susceptible to chilling injury at the breaker stage of ripeness. HortScience 42:1659-1664.

Lin, W.C., J.W. Hall, and M.E. Saltveit. 1993. Ripening stage affects the chilling sensitivity of greenhouse grown peppers. J. Amer. Soc. Hort. Sci. 118:791-795.

Lipton, W.J. and Y. Aharoni. 1979. Chilling injury and ripening of 'Honey Dew' muskmelons stored at 2.5 or $5{ }^{\circ} \mathrm{C}$ after ethylene treatment at $20^{\circ} \mathrm{C}$. J. Amer. Soc. Hort. Sci. 104:327-330.

Lurie, S. and S. Ben-Yehoshua. 1986. Changes in membrane properties and abscisic acid during senescence of harvested bell pepper fruit. J. Amer. Soc. Hort. Sci. 111:880-885.

Malacrida, C., E.M. Valle, and S.B. Boggio. 2006. Postharvest chilling induces oxidative stress response in the dwarf tomato cultivar MicroTom. Physiol. Plant. 127:10-18.

Marangoni, A.G., T. Palma, and D.W. Stanley. 1996. Membrane effects in postharvest physiology. Postharvest Biol. Technol. 7:193217.

Marangoni, A.G. and D.W. Stanley. 1989. Phase transitions in microsomal membranes from chilling sensitive and chilling resistant tomato plants and fruit. Phytochemistry 28:2293-2301.

Meir, S., I. Rosenberger, Z. Aharon, S. Grinberg, and E. Fallik. 1995. Improvement of the postharvest keeping quality and color development of bell pepper (cv. 'Maor') by packaging with polyethylene bags at a reduced temperature. Postharvest Biol. Technol. 5:303309 . 
Nagano, Y. and K. Asada. 1981. Hydrogen peroxide is scavenged by ascorbate specific peroxidase in spinach chloroplast. Plant Cell Physiol. 22:867-880.

Nagata, M. and I. Yamashita. 1992. Simple method for simultaneous determination of chlorophyll and carotenoids in tomato fruit. J. Jpn. Soc. Food Sci. Technol. 39:925-928.

Namiki, M. 1990. Antioxidants/antimutagens in food. CRC Crit. Rev. Food Sci. Nutr. 29:273-300.

Paull, R.E. 1990. Chilling injury of crops of tropical and subtropical origin, p. 17-36. In: Wang, C.Y. (ed.). Chilling injury of horticultural crops. CRC Press, Boca Raton, FL.

Purvis, A.C. 2002. Diphenylamine reduces chilling injury of green bell pepper fruit. Postharvest Biol. Technol. 25:41-48.

Purvis, A.C. and R.L. Shewfelt. 1993. Does the alternative pathway ameliorate chilling injury in sensitive plant tissues? Physiol. Plant. 88:712-718.

Purvis, A.C., R.L. Shewfelt, and J.W. Gegogeine. 1995. Superoxide production by mitochondria isolated from green bell pepper fruit. Physiol. Plant. 94:743-749.

Risse, L.A., D. Chun, and W.R. Miller. 1987. Chilling injury and decay of film-wrapped and conditioned bell pepper during cold storage. Trop. Sci. 27:85-90.

Rupasinghe, H.P.V., G. Paliyath, and D.P. Murr. 2000. Sesquiterpene $\alpha$-farnesene synthase: Partial purification, characterization, and activity in relation to superficial scald development in apples. J. Amer. Soc. Hort. Sci. 125:111-119.
Sala, J.M. 1998. Involvement of oxidative stress in chilling injury in cold-stored mandarin fruits. Postharvest Biol. Technol. 13:255261.

Sala, J.M. and M.T. Lafuente. 1999. Catalase in the heat-induced chilling tolerance of cold-stored hybrid Fortune mandarin fruits. J. Agr. Food Chem. 47:2410-2414.

Sala, J.M. and M.T. Lafuente. 2004. Antioxidant enzymes activities and rindstaining in 'Nevelina' oranges as affected by storage relative humidity and ethylene conditioning. Postharvest Biol. Technol. 31:277-285.

Saltveit, M.E. 2002. The rate of ion leakage from chilling-sensitive tissue does not immediately increase upon exposure to chilling temperatures. Postharvest Biol. Technol. 26:295-304.

Saruyama, H. and M. Tanida. 1995. Effect of chilling on activated oxygen-scavenging enzymes in low temperature-sensitive and -tolerant cultivars of rice (Oryza sativa L.). Plant Sci. 109:105-113.

Scandalios, J.G. 1993. Oxygen stress and superoxide dismutase. Plant Physiol. 101:7-12.

Schantz, M.L., H. Schreiber, P. Guillemaut, and R. Schantz. 1995. Changes in ascorbate peroxidase activities during fruit ripening in Capsicum annuum. FEBS Lett. 358:149-152.

Shen, W., K. Nada, and S. Tachibana. 1999. Effect of cold treatment on enzymic and nonenzymic antioxidant activities in leaves of chillingtolerant and chilling-sensitive cucumber cultivars. J. Jpn. Soc. Hort. Sci. 68:967-973.

Zhang, J., S. Cui, J. Li, J. Wei, and M.B. Kirkham. 1995. Protoplasmic factors, antioxidant responses, and chilling resistance in maize. Plant Physiol. Biochem. 33:567-575. 